\title{
LIPID INTAKE AND SERUM CHOLESTEROL LEVEL IN CYSTIC FIBROSIS PATIENTS
}

\author{
A. MADARASi, ${ }^{a}$ E. GREINER, ${ }^{b}$ R. ÚJHELYI, ${ }^{c}$ E. SÓLYOMd ${ }^{d}$, L. BíRÓ, ${ }^{b}$ E. MOZSÁRY, ${ }^{b}$ \\ A. REGÖLYI-MÉREI ${ }^{b}$ and M. ANTAL ${ }^{b}$ \\ a Buda Children's Hospital, H-1023 Budapest, Bolyai u. 5-7. Hungary \\ ${ }^{\mathrm{b}} \mathrm{NCPH}-$ National Institute of Food Hygiene and Nutrition, H-1097 Budapest, Gyáli út 3/a. Hungary \\ c Heim Pál Children’s Hospital, H-1089 Budapest, Üllői út 86. Hungary \\ d Borsod County Teaching Hospital, Child Health Center, H-3501 Miskolc, \\ Szentpéteri kapu 72-76. Hungary
}

(Received: 19 April 1999; accepted: 20 June 1999)

\begin{abstract}
The authors evaluated the data of 30 patients with cystic fibrosis ( 18 male, 12 female), between ages 2-18 (average age: 9.57 years). In $60 \%$ of the patients serum cholesterol was below the 5th percentile value according to the data of the NATIONAL CHOLESTEROL EDUCATION PROGRAM (1991). They examined the connection between the serum cholesterol levels and the total fat, fatty acids and cholesterol intake. No significant differences were found between total fat, fatty acids and cholesterol intake of patients with serum cholesterol levels below the 5th percentile value and patients with levels above the 5 th percentile value. The analysis of the nutritional data showed that lipid intake was in accordance with the proportion prescribed for patients with CF (35.56\% of energy). The intakes of saturated fatty acids (SFA), monounsaturated fatty acids (MUFA) and polyunsaturated fatty acids (PUFA) were $11 \%, 11 \%$ and $8,3 \%$ of total energy, respectively, the PUFA/SFA ratio was 0.78 . The ratio of linoleic to alfa-linolenic acid was especially high: 29 . The clinical condition of the patients in the low cholesterol level group, as shown by the Shwachman-Kulczycki score was significantly lower $(\mathrm{P}<0.05)$ than that of the group with serum cholesterol levels above the 5 th percentile value. The authors therefore suggest the importance of the regular monitoring of serum cholesterol levels in patients with cystic fibrosis. Observing the changes in serum cholesterol levels is a fast, informative and inexpensive method of evaluating the clinical course of the disease.
\end{abstract}

Keywords: cystic fibrosis, serum cholesterol, nutrient intake

Cystic fibrosis (CF) is one of the most common life-threatening, metabolic diseases with an autosomal recessive pattern of inheritance. There is virtually no other chronic disease, where the nutritional state plays such a crucial role in the progression (ROULET, 1994). The fate of patients with CF is determined mainly by the state of their lungs (BEDDOES et al., 1981; DODGE, 1992). It has been conclusively proven that adequate nutritional state slows the progression of the pulmonary process and results in 
increased life expectancy and better life conditions for the patients (ANTHONY et al., 1998.; MietTIEN, 1972.; RoUlet, 1994.). This is why physicians treating CF patients place special emphasis on the evaluation of the nutritional state and related issues (CABRERA et al., 1994; CANNELA et al.,1993, MARCUS et al., 1991; PlATA-SALAMÁN, 1996; SólYOM, 1996).

The aim of our study was to examine the cause and clinical significance of the decreased levels of serum cholesterol seen in patients with CF. We compared the nutrients intake - focusing on total fat, fatty acids and cholesterol - of patients with low levels of serum cholesterol and patients with serum cholesterol level above the 5th percentile value.

\section{Methods}

The study was carried out on 30 patients ( 18 male, 12 female) between 1 and 18 years of age (average age: 9.57 years) with cystic fibrosis, recruited from the outpatient department for a scheduled follow up visit. All patients and their parents volunteered for the study, which had been accepted by the ethical committee of Haynal Imre University of Health Sciences. The disease was diagnosed based on the clinical signs and the elevated levels of sweat chloride ( $\left.>60 \mathrm{mmol} \mathrm{l}^{-1}\right)$; all of the patients underwent mutation studies (Table 1).

The clinical condition of the patients was evaluated with the ShwachmanKulczycki score (SHWACHMAN \& KULCZYCKI, 1958). As the analysis of stool lipid excretion was not feasible for all of the children involved in the study, the dosage of the enzyme substitution was set ensure one or maximum two stools of normal consistency daily. The average lipase intake of our patients was $\sim 5000 \mathrm{IU} \mathrm{kg}^{-1} / \mathrm{day}$.

Table 1

Mutations of cystic fibrosis patients $(n=30)$

\begin{tabular}{cl}
\hline Number of patients & Mutation \\
\hline 15 & $\Delta$ F508/ $\Delta$ F508 \\
4 & $\Delta$ F508/N \\
2 & $\Delta$ F508/R553X \\
2 & $\Delta$ F508/G542X \\
1 & R553X/N \\
1 & N/W1282X \\
5 & $\mathrm{~N} / \mathrm{N}$ \\
\hline
\end{tabular}


Participants had previously received three questionnaires prepared for recording meals consumed on 2 weekdays and on the last Sunday before the examination. The method of $3 \times 24 \mathrm{~h}$ dietary record has been applied together with $1 \times 24 \mathrm{~h}$ recall made by a trained dietitian. The energy and nutrient intakes were calculated on the basis of the nutrient data bank and computer program, both developed by the National Institute of Food Hygiene and Nutrition (Bíró et al., 1996., GANJI et al., 1998).

Laboratory measurements were performed as follows:

- Hepatic enzymes, alkaline phospatase, albumin were measured on a Hitachi 704 clinical analyzer with commercially available kits.

- Total cholesterol, triglyceride, HDL-cholesterol, LDL-cholesterol, Apo A, Apo B concentrations were measured with Roche analytical kits with a Cobas Mira Plus analyzer.

Statistical analysis was performed with the SPSS software program: means were calculated for all values, comparison was performed with the ANOVA method (significance level $\mathrm{P}<0.05$ ) and linear regression was calculated (significance level $\mathrm{P}<0.05)$.

\section{Results}

Table 2 summarizes the most important clinical data and nutrient intake of the children involved in the study. The children were assigned to one of two groups based on their serum cholesterol level (Table 3). Group 1 consisted of patients whose serum cholesterol level was above the 5 th percentile value for their age group and sex. Group 2 consisted of patients, whose serum cholesterol level did not reach the 5th percentile value (NATIONAL CHOLESTEROL EDUCATION PROGRAM, 1991).

The analysis of the two groups reveals the following:

- there was no significant difference between values of the body mass index

- the Shwachman-Kulczycki score, indicative of the clinical condition of the patient was significantly higher in children, whose level of serum cholesterol was above the 5 th percentile norm $(\mathrm{P}<0.05)$

- there was no significant difference between the two groups in total energy, fat-, cholesterol-, carbohydrate and protein energy intake,

- PUFA, MUFA- and SFA-energy percentages of the two groups did not show significant differences either,

- PUFA/SFA ratio was 0.78 ,

- ratio of linoleic acid to alfa-linolenic acid was exceptionally high: 29,

- the intake of fibers was $23 \mathrm{~g}$. 
Table 2

Some clinical data and nutrient intake of cystic fibrosis patients with different serum cholesterol levels

\begin{tabular}{|c|c|c|c|c|}
\hline \multirow[t]{2}{*}{$\begin{array}{l}\text { Clinical data and nutrient } \\
\text { intake }\end{array}$} & \multicolumn{2}{|c|}{$\begin{array}{c}\text { Group } 1 \\
n=12\end{array}$} & \multicolumn{2}{|c|}{$\begin{array}{c}\text { Group } 2 \\
n=18\end{array}$} \\
\hline & Mean & $\pm \mathrm{SD}$ & Mean & $\pm \mathrm{SD}$ \\
\hline Age (year) & 9.6 & 3.15 & 9.6 & 3.67 \\
\hline Body mass index (BW kg m${ }^{-2}$ ) & 15 & 1.91 & 16 & 3.13 \\
\hline Shwachman-Kulczycki score & 89.2 & $12.03 \mathrm{a}$ & 81.1 & $8.50 \mathrm{a}$ \\
\hline Energy $\left(\mathrm{kcal} \mathrm{BW} \mathrm{kg}^{-1}\right)$ & 105.7 & 32.22 & 104.6 & 32.70 \\
\hline Cholesterol (mg) & 408 & 206.2 & 376 & 95.5 \\
\hline Cholesterol (mg BW kg$\left.{ }^{-1}\right)$ & 14.7 & 4.29 & 15.1 & 5.54 \\
\hline Fat $\%$ of energy & 35.6 & 3.26 & 35.5 & 3.68 \\
\hline Carbohydrate $\%$ of energy & 49 & 3.5 & 49 & 4.0 \\
\hline Protein \% of energy & 15.1 & 1.85 & 15.5 & 2.08 \\
\hline PUFA \% of energy & 7.8 & 1.77 & 8.8 & 2.52 \\
\hline MUFA \% of energy & 11.1 & 1.91 & 10.5 & 1.61 \\
\hline SFA \% of energy & 11.7 & 1.90 & 11.1 & 2.15 \\
\hline $\mathrm{P} / \mathrm{S}$ & 0.7 & 0.23 & 0.8 & 0.40 \\
\hline Fibers $(\mathrm{g})$ & 25.3 & 5.81 & 22.4 & 7.06 \\
\hline Linoleic acid (g) & 22.4 & 7.23 & 24.2 & 7.43 \\
\hline$\alpha$-Linolenic acid (g) & 0.9 & 0.34 & 0.8 & 0.27 \\
\hline Linoleic/ $\alpha$-Linolenic acid & 26 & 8.2 & 33 & 13.2 \\
\hline
\end{tabular}

Means followed by the same letters are significantly different at $\mathrm{P}<0.05$ level between the columns Group 1: serum cholesterol level $>5$ th percentile Group 2: serum cholesterol level $<5$ th percentile

Table 3

Serum total cholesterol 5 th percentil levels according to the National cholesterol Education Program, (1991), USA

\begin{tabular}{lcc}
\hline $\begin{array}{c}\text { Age } \\
\text { (year })\end{array}$ & \multicolumn{2}{c}{$\begin{array}{c}\text { Serum total cholesterol level } \\
\left(\mathrm{mmol} \mathrm{l}^{-1}\right)\end{array}$} \\
\hline & Males & Females \\
$0-4$ & 3.03 & 2.97 \\
$5-9$ & 3.20 & 3.36 \\
$10-14$ & 3.18 & 3.28 \\
$15-19$ & 2.98 & 3.18 \\
\hline
\end{tabular}

Acta Alimentaria 28, 1999 
Table 4

Biochemical indices of cystic fibrosis patients with different serum cholesterol levels

\begin{tabular}{|c|c|c|c|c|}
\hline \multirow[t]{2}{*}{ Biochemical indices } & \multicolumn{2}{|c|}{$\begin{array}{c}\text { Group } 1 \\
n=12\end{array}$} & \multicolumn{2}{|c|}{$\begin{array}{c}\text { Group } 2 \\
n=18\end{array}$} \\
\hline & Mean & $\pm \mathrm{SD}$ & Mean & $\pm \mathrm{SD}$ \\
\hline Serum cholesterol $\left(\mathrm{mmol} \mathrm{l}^{-1}\right)$ & 3.9 & $0.53 b$ & 2.7 & $0.38 b$ \\
\hline Serum HDL-cholesterol $\left(\mathrm{mmol}^{-1}\right)$ & 1.2 & $0.29 b$ & 0.9 & $0.20 \mathrm{~b}$ \\
\hline Serum LDL-cholesterol(mmol 1-1) & 2.2 & $0.58 b$ & 1.3 & $0.37 b$ \\
\hline Serum ApoA $\left(\mathrm{g}^{-1}\right)$ & 1.4 & $0.22 \mathrm{a}$ & 1.2 & $0.19 a$ \\
\hline Serum ApoB $\left(\mathrm{g} \mathrm{l}^{-1}\right)$ & 0.7 & $0.12 b$ & 0.6 & $0.09 b$ \\
\hline Serum triglycerides $\left(\mathrm{mmol} \mathrm{l}^{-1}\right)$ & 1.0 & 0.38 & 0.8 & 0.36 \\
\hline Serum uric acid $\left(\mathrm{mmol}^{-1}\right)$ & 259.4 & 78.97 & 294.9 & 69.26 \\
\hline Serum albumin $\left(\mathrm{g}^{-1}\right)$ & 45.2 & $1.75 \mathrm{a}$ & 43.6 & $2.23 \mathrm{a}$ \\
\hline SGOT $\left(\mathrm{U}^{-1}\right)$ & 27.3 & 12.82 & 23.4 & 6.67 \\
\hline SGPT (U 1 $\left.{ }^{-1}\right)$ & 22.9 & 14.66 & 16.5 & 7.31 \\
\hline GGT (U 1 $\left.1^{-1}\right)$ & 16.5 & 8.67 & 16.7 & 8.92 \\
\hline Serum alkaline phosphatase $\left(\mathrm{U}^{-1}\right)$ & 661.7 & 204.30 & 684.9 & 196.65 \\
\hline
\end{tabular}

Means followed by the same letters are significantly different at $\mathrm{a}: \mathrm{P}<0.05, \mathrm{~b}: \mathrm{P}<0.01$ between the column, respectively

Group 1: serum cholesterol level $>5$ th percentile

Group 2: serum cholesterol level $<5$ th percentile

Table 4 shows some clinical data and laboratory findings of the two groups as follows:

- from the biomarkers relating to nutritional status, serum albumin was significantly lower in patients with serum cholesterol below the 5 th percentile value $(\mathrm{P}<0.05)$,

- there was no significant difference between the values of the hepatic enzymes and alkaline phosphatase,

- serum cholesterol, HDL-cholesterol, LDL-cholesterol, Apo A and Apo B concentrations were significantly higher in group 1.

\section{Discussion}

The basis of cystic fibrosis is a mutation of the cystic fibrosis transmembrane regulator (CFTR) gene located on the long arm of the 7 th chromosome, resulting in the inability of the CFTR protein in the plasma membrane of the epithelial cells to regulate the cAMP stimulated chloride channels of the cell membrane. This results in the 
production of mucus with abnormal composition, which causes irreversible damage primarily in the airways and the digestive system. Faultless functioning of the plasma membrane necessitates adequate quantities of cholesterol (BíRÓ, 1990.; IRIBARREN et al., 1995.). This phenomenon call attention to the importance of our observation that a considerable proportion of our patients treated for cystic fibrosis ( $60 \%$ in this study) the serum levels of cholesterol were below the 5 th percentile value, in spite of the fact that the intake of fat, fatty acids and cholesterol - both in absolute value and per $\mathrm{kg}$ of body weight - in these children was not less than that of the patients with cystic fibrosis with serum cholesterol levels above the 5 th percentile value.

We did not find any difference between the amount - which was in accordance with the guidelines set for children with cystic fibrosis $35.6 \%$ of energy) (DODGE, 1992. , MACDONALD, 1996) - or composition of the lipid intake of the two groups: SFAs, MUFAs and PUFAs were approximately $11 \%, 11 \%$ and $8 \%$ of total energy, respectively. Therefore we propose that the low levels of serum cholesterol were due to a disorder in the endogenous cholesterol synthesis. Due to the parthomechanism of the disease, this disorder can manifest in all patients with cystic fibrosis, as the lack of the CFTR protein affects the epithelial cells of the liver and the biliary tract. Long-term course of the disease lead to biliary cirrhosis, which can result in decreased levels of cholesterol in multiple ways: decreased synthesis of cholesterol, and decrease in the quantities of cholesterol salvaged via the entero-hepatic circulation (GYLLING et al., 1995; MieTTIEN, 1972). Apo A and Apo B are the main components of HDL- and LDLcholesterol, respectively. The major sites of the synthesis of these proteins are the liver and the intestine. It is a clear trend towards the low levels of total cholesterol and Apo A reflecting the severity of liver injury. Moreover, the low Apo B concentration may be connected to the impaired hepatic synthesis of this apolipoprotein (GRUNDY, 1999, RIESEN \& KLOER, 1989). Our data are in good accordance with these statements. It should also be noted that treatment with modern enzyme products do not ensure perfect absorption of fats, cholesterol and other nutrients (BERNABDESLAM et al., 1998, KALIVIANAKIS et al., 1999).

We studied the levels of hepatic enzymes, serum alkaline phosphatase and found no significant difference between the two groups. In other words we need a different kind of parameter which is suitable for the evaluation of hepatic damage. For this reason we suggest that the monitoring of serum cholesterol levels is an important and sensitive method for all patients with cystic fibrosis.

We also investigated the importance of the high linoleic acid intake (EGMOND et al., 1996) and the high ratio of linoleic to alfa-linolenic acid intake of our patients. An increase in linoleic acid (n-6 PUFA) intake results in a lowering of plasma LDLcholesterol concentration. This effect may not be linear and most of the benefits appear to be gained by moving from lower to moderate ( $4-5 \%$ of energy) intake. Whereas a 
shift between 15 and $20 \%$ of energy as linoleic acid, is often without effect. Moreover, it is worthy to note that the effects of dietary n-6 PUFAs are less than half of that of lowering dietary saturated fatty acids. Therefore, if total fat intake is maintained, the LDL-cholesterol lowering effects of increasing linoleic acid intake are greatly enhanced if saturated fatty acid intake is decreased (HODGSON \& WAHLQVIST, 1999). To maintain the alveolar membrane integrity a sufficient docosahexaenoic acid (n-3, DHA C22:6) content is absolutely necessary. When the ratio of linoleic to alfa-linolenic acid intake is so high, the synthesis of DHA from alfa-linolenic acid is inhibited. So it would be absolutely important to improve ratio of linoleic and alfa-linolenic acid with increasing alfa-linolenic acid content of the diet of patients with cystic fibrosis (KATZ et al., 1996).

Summarizing our results it has been found that low serum cholesterol level with adequate lipid, cholesterol intake and enzyme substitution implies an impaired cholesterol absorption and/or hepatic lesion with connection to the severity of cystic fibrosis. We would like to stress the importance of our finding, which shows a significant correlation between low cholesterol levels and the Shwachman-Kulczycki (SCHWACHMAN \& KULCZYCKI, 1958) score, used since 1958 for the evolution of the clinical status of patients with cystic fibrosis: children with decreased levels of cholesterol have lower scores, their clinical condition is worse.

\section{References}

Anthony, H., Bines, J., Phelan, P. \& PAXTON, S. (1998): Relation between dietary intake and nutritional status in cystic fibrosis. Arch. Dis. Child., 78, 443-447.

BedDOES, V., LAING, S., GOODCHILD, M. C. \& DODGE, J. A. (1981): Dietary management of cystic fibrosis. Practitioner, 225, 557-560.

BernabDeSlam, H., GARCiA, I., Bellon, G., Gilly, R. \& REVOL, A. (1998): Biochemical assessment of the nutritional status of cystic fibrosis patients treated with pancreatic enzyme extracts. Am. J. Clin. Nutr., 67, 912-918.

BíRÓ, GY. (1990): A zsírok táplálkozásélettani szempontból. (Fats in respect of nutrition physiology.) Élelmezési Ipar, 11, 393-395.

BÍRÓ, GY., ANTAL, M. \& ZAJKÁS G. (1996): Nutrition survey of the Hungarian population in randomized trial between 1992-1994. Eur. J. Clin. Nutr., 50, 201-208.

CABrera, M. E., Lough, M. D., DOershuK, C. F. \& SAlvator, A. E. (1994): An expanded scoring system including an index of nutritional status for patients with cystic fibrosis. Pediatr. Pulmonol., 18, 199-205.

CANNella, P. C., BOwSter, E. K., GuYer, L. K. \& BORUM, P. R. (1993): Feeding practices and nutrition recommendations for infants with cystic fibrosis. J. Am. Diet. Assoc., 93, 297-300.

DODGE, J. A. (1992): Nutrition in cystic fibrosis: a historical overview. Proc. Nutr. Soc., 51, 225-235.

EGMOND, A. W., KOSOROK, M. R., KOSCIK, K. R., LAXOVA, A. \& FARREL, P. M. (1996): Effect of linoleic acid intake on growth of infants with cystic fibrosis. Am. J. Clin. Nutr., 63, 746-752.

GANJ, V., HAMPL, J. S. \& BETTS, N. M. (1998): Macronutrients, cholesterol, sodium and fiber intakes of 1-10 year old children by age, gender and race. Nutr. Res., 3, 465-473. 
GRUNDY, S. M. (1999): Factors determining blood cholesterol levels. -in: SADLER, M. J., STRAIN, J. J. \& CABAllero, B. (Eds) Encyclopedia of human nutrition, Academic Press, San Diego, London, pp. $376-382$.

GYLling, H., FrakKilA, M., VuORISTO, M. \& MiETTINEN, T. A. (1995): Metabolism of cholesterol and lowand high-density lipoproteins in primary biliary cirrhosis: cholesterol absorption and synthesis related to lipoprotein levels and their kinetics. Hepatology, 21, 89-95.

HODGSON, J., WAHLQVITS, ML. (1999): Health effects of n-6 polyunsaturated fatty acids. -in: SANDLER, M. J., StRAin, J. J. \& CABAllero, B. (Eds) Encyclopaedia of human nutrition, Academic Press, San Diego, London, pp. 751-752.

IrIBARREN, C., REED, D. M., CHEN, R., YANO, K. \& DWYER, J. (1996): Low serum cholesterol and mortality. Which is the cause and which is the effect? Circulation, 92, 2396-2403.

Kalivianakis, M., MiniCh, D. M., BiJleveld, C. M. A., AALderen, W. M. C., StellaArd, F., LaSEuR, M., VONK, R. J. \& VERKADE, H. J. (1999): Fat malabsorption in cystic fibrosis patients receiving enzyme replacement therapy is due to impaired intestinal uptake of long-chain fatty acids. $A m$. J. Clin. Nutr., 69, 127-134.

KATZ, A. P., MANNER, T., FURST, P., \& ASKANAYI, J. (1996): The use of an intravenous fish oil emulsion enriched with omega/3 fatty acids in patient with cystic fibrosis. Nutrition, 12, 334-336.

MACDONALD, A. (1996): Nutritional management of cystic fibrosis. Arch. Dis. Child., 74, 81-87.

MARCuS, M. S., SONDEl, S. A., FARrel, P. M., LAXOYA, A., CAREY, P. M., LANGHOUGH, R. \& MiSCHLER, E. H. (1991): Nutritional status of infants with cystic fibrosis associated with early diagnosis and intervention. Am. J.Clin. Nutr., 54, 578-585.

MIETTIEN, T. A. (1972): Lipid absorption, bile acids and cholesterol metabolism in patients with chronic liver disease. Gut, 13, 682-689.

NATIONAL CHOLESTEROL EDUCATION PROGRAM (1991): Report of the expert panel on blood cholesterol levels in children and adolescents. NIH Publication, 17-19.

NATIONAL RESEARCH COUNCIL, FOOD AND NUTRITION BOARD (1989): Recommended Dietary Allowances. 10th ed., National Academy Press, Washington DC.

PLATA-SALAMÁN, C. R. (1996): Anorexia during acute and chronic disease. Nutrition, 12, 69-78.

RIESEN, W. F. \& KlOER, H. (1989): Dyslipoproteinemias and liver disease. -in: FruCHART, J. C. \& SHEPHERD, J. (Eds) Human plasma liporoteins. W de Gruyter, Berlin, NY, pp. 219-230.

Roulet, M. (1994): Protein-energy malnutrition in cystic fibrosis patients. Acta Pediatr... Suppl., 395, $43-48$.

SHWACHMAN, H. \& KULCZYCKI, L. L. (1958): Long-term study of one hundred five patients with cystic fibrosis. Am. J. Dis. Child., 96, 6-15.

SÓLYOM, E. (1996): A cystás fibrosis (mucoviscidosis) komplex kezelése, különös tekintettel a táplálásra. (Complex management of cystic fibrosis of high priority of nutrition.) Táplálk. Anyagcs. Diéta, $3,23-28$. 